and without gestational diabetes", J Nat Sci Biol Med, 4 (2), pp. 302-305.

3. Faranak $S$, Amir Z (2010). "Serum ferritin concentration in gestational diabetes mellitus and risk of subsequent development of early postpartum diabetes mellitus", Diabetes Metab Syndr Obes, 3, pp. 413-419.

4. Kale S D, Kulkarni S, et al (2005). "Characteristics of gestational diabetic mothers and their babies in an Indian diabetes clinic", JAPI, 53, pp. 857-863.

5. Preeti C, Parijat G, et al (2020). "Association of Maternal Serum Ferritin Level in Gestational Diabetes Mellitus and its Effect on Cord Blood Hemoglobin", International Journal of
Contemporary Medical Research, 7 (1), pp. A1-A4.

6. Soheilykhah $S$, Mojibian $M$, et al (2017). "Serum ferritin concentration in early pregnancy and risk of subsequent development of gestational diabetes: A prospective study", International Journal of Reproductive BioMedicine, 15 (3), pp. 155-160.

7. Wang Z, Fan H B, et al (2018). "Correlation between plasma ferritin level and gestational diabetes mellitus and its impact on fetal macrosomia", Journal Diabetes Investigation, 9 (6), pp. 1354-1359.

8. Zein S, Rachidi S, et al (2015). "High iron level in early pregnancy increased glucose intolerance", j Trace Elem Med Biol, 30, pp. 220-225.

\title{
KẾT QUẢ NộI SOI CHẨN ĐOÁN BỆNH LÝ Ổ BỤNG TẠI BỆNH VIỆN ĐẠI HỌC Y HÀ NộI
}

\section{TÓM TẮT}

Mục tiêu nghiên cứu: Mô tả đặc điểm lâm sàng, cận lậm sàng, chỉđịnh và đánh giá kết quả của phẩu thuật nội soi chẩn đoán bệnh lý ổ bung tại bệnh viện đai hoc $Y$ Hà Nội. Phương pháp nghiến cứu: Nghiên cứu mô tả hồi cứu, bệnh nhân được phẫu thuâtt nội soi chẩn đoán bênh lý ổ bung tai Bểnh viên Đại học Y Hà Nội từ 2015 đến 2019. Kết quả nghiên cứu: Kết quả nội soi ổ bụng chẩn đoán 38 bệnh nhân, trong đó có $34(89,5 \%)$ bệnh nhân là lao phúc mac, có $3(7,9 \%)$ bệnh nhân kết quả là viêm mạn tính và $1(2,6 \%)$ bệnh nhân là ung thư di căn phúc mạc. Tuổi trung bình $52,3 \pm 17,8$. Tỉ lệ Nữ/Nam là $1,1 / 1$. Thời gian phẫu thuật trung bình $49,5 \pm 9,1$ phút. Thời gian nằm viện sau mổ trung bình $4,6 \pm 1,2$ ngày. Khô̂ng gặp biến chứng trong và sau mổ. Kết luận: Phẫu thuật nội soi chẩn đoán bệnh lý ổ bụng là phương pháp an toàn, hiệu quả và chính xác giúp chẩn đoán nguyên nhân các bệnh lý ổ bụng.

Tư khoá: nội soi ổ bụng chẩn đoán, phẫu thuật nội soi ổ bụng chẩn đoán.

\section{SUMMARY}

\section{OUTCOME OF DIAGNOSTIC LAPAROSCOPY}

IN CHRONIC ABDOMINAL CONDITIONS WITH UNCERTAIN DIAGNOSISAT HA NOI MEDICAL UNIVERSITY HOSPITAL

Objectives: To describe clinical characteristics, laboratory results and evaluate early outcomes of Diagnostic laparoscopyat $\mathrm{Ha}$ Noi medical University hospital. Methods: Cross sectional, descriptive retrospective studys. Results: There were 34

\section{${ }^{1}$ Dại học Y Hà Nội}

Chịu trách nhiệm chính: Đặng Quốc Ái

Email: drdangquocai@gmail.com

Ngày nhận bài: 12.4.2021

Ngày phản biện khoa học: 24.5.2021

Ngày duyệt bài: 14.6.2021
Lê Anh Tuấn ${ }^{1}$, Đặng Quốc Ái ${ }^{1}$, Hà Văn Quyết ${ }^{1}$

$(89,5 \%)$ cases of peritoneal tuberculosis, $3(7,9 \%)$ cases of chronic inflammation and the rest of cancer. Average age was 52,3 $\pm 17,8$. Female / Male ratio: $1.1 / 1$. Mean surgical time was $49,5 \pm 9,1$ minutes. The average postoperative day of hospitalization was $4,6 \pm 1,2$ days. No intra-operative complications. Conclusion: Chronic Abdominal Conditions with Uncertain Diagnosis can be diagnosed safely and precisely by diagnostic laparoscopy.Keywords: Diagnostic laparoscopy.

Keywords: Diagnostic laparoscopy

\section{I. ĐẶT VẤN ĐỀ}

Nội soi ổ bụng được thực hiện đầu tiên tại Mỹ vào Năm 1911, do Bertram Bernheim thực hiện. Ông không bơm hơi ổ bụng và thấy được dạ dày, túi mật, gan và phúc mạc qua một scope $12 \mathrm{~mm}$ ở thượng vị [4]. Năm 1937, Ruddock thực hiện nội soi chẩn đoán thành công trên 500 bệnh nhân mà không có trường hợp nào tử vong. Từ đó nội soi ổ bụng trở thành một phương tiện chẩn đoán các bệnh khung chậu và trong ổ bụng [7]. Tuy nhiên, nội soi ổ bụng chỉ cho phép quan sát được sơ lược các tạng trong ổ bụng mà không thể đánh giá được chính xác tổn thương, đặc biệt là các vị trí khổng được bộc lộ, việc lấy bểnh phẩm làm xét nghiệm cững rất khó khăn, dẩn đến không chẩn đoán chính xác được trong nhiều ca bênh.

Với sự phát triển mạnh mẽ của phẫu thuật nội soi trên toàn thế giới, phẫu thuật nội soi ổ bụng chẩn đoán đã phát triển nhanh chóng , khắc phục được những hạn chế của nội soi ố bụng, giúp chẩn đoán chính xác thương tổn các tạng trong ổ bụng và thực hiện xử trí tổn thương tương đối dễ dàng, nhất là ở những vị trí chật hẹp nằm sâu trong ổ bụng, đồng thời lấy được 
bệnh phẩm xét nghiệm chẩn đoán chính xác bệnh. Nghiên cứu này của chúng tôi được thực hiện nhằm "Đánh giá kêt quả mổ nội soi chẩn đoán bệnh lý ổ bụng tại bệnh viện Đại học Y Hà Nội".

\section{II. ĐỐI TƯỢNG VÀ PHƯƠNG PHÁP NGHIÊN CỨU}

2.1. Đối tượng nghiên cứu: Tất cả những bệnh nhân được phẫu thuật nội soi chẩn đoán bểnh lý ổ bụng tại khoa Ngoại Tổng Hợp - Bệnh viện Đại học Y Hà Nội từ tháng 01/2015 đến tháng 12/2019.

Tiêu chuẩn lựa chọn: Các bệnh nhân có bệnh lý ổ bụng nhưng chưa xác định được nguyên nhân bằng thăm khám lâm sàng, xét nghiệm máu, siêu âm và chụp cắt lớp vi tính và thâm chí chọc dò ổng bụng dưới hướng dẫn của siêu âm để lấy dịch làm chẩn đoán.

\section{Tiêu chuân loại trừ:}

+Các bệnh nhân nội soi ổ bụng chẩn đoán và điều trị chẩn thương bụng, vết thương bụng.

+ Các bệnh nhân có các bệnh khác như sản phụ khoa, tinh hoàn ẩn, ung thư... đã có chẩn đoán trước và phẫu thuật nội soi chỉ mang tính chất thăm dò để đánh giá giai đoạn.

2.2. Phương pháp nghiên cứu: Nghiên cứu mô tả hồi cứu, chọn mẫu thuận tiện.

\subsection{Phương pháp phẫu thuật:}

\section{Chỉ đinh:}

- Tất cả những bênh nhân có bênh lý ổ bụng nhưng chưa xác định được chẩn đoán qua thăm khám lâm sàng, cận lâm sàng và các thủ thuật thăm dò khác.

- Không có chống chỉ định về mă̆t gây mê hồi sức.

- Không có chống chỉ định phẫu thuật nội soi.

\section{Kỹ thuật:}

- Bệnh nhân được gây mê nội khí quản.

- Đắt 03 trocars: 1 trocar $10 \mathrm{~mm}$ ở rốn, 2 trocả $5 \mathrm{~mm}$ còn lại thông thường sẽ đặt ở hố chậu hai bên. Tuy nhiên cũng có những trường hợp chỉ cần đặt 2 trocar.

- Bộc lộ, quan sát, nhận định và đánh giá dịch ổ bụng, phúc mạc và các tạng trong ổ bụng để phát hiện các thướng tổn về mă̆t đại thể.

- Lấy dịch làm xét nghiệm tế bào và nuôi cấy vi khuẩn.

- Lấy bệnh phẩm phúc mạc, mạc nối, hạch ... làm giải phẫu bệnh.

\section{KẾT QUẢ NGHIÊN CỨU}

3.1. Đặc điểm lâm sang. Trong nghiên cứu của chúng tôi có 38 bệnh nhân, trong đó có 20 bệnh nhân nam chiếm $52.6 \%$ và 18 bệnh nhân nữ chiếm 47,4\%. Độ tuổi trung bình của nhóm nghiên cứu là $52,3 \pm 17,8$, tuổi bệnh nhân cao nhất là 90 tuổi, thấp nhất là 17 tuổi.
Các triệu chứng lâm sàng của bệnh nhân gồm có: $57,9 \%$ sốt, $63,2 \%$ đau bụng, $97,4 \%$ chướng bụng, $63,2 \%$ rối loạn tiêu hóa.

3.2. Đặc điểm cận lâm sang. Cả 38 bệnh nhân được xét nghiệm Rivalta và chọc dò dịch ổ bụng làm xét nghiệm Protein đều cho kết quả Rivalta dương tính và Protein dịch $\geq 30 \mathrm{~g} / \mathrm{L}$. Có 31 bệnh nhân được làm xét nghiệm phản ứng IDR lao, kết quả $10(32,2 \%)$ bệnh nhân dương tính. Trong đó 5 bệnh nhân được làm xét nghiệm AFB đờm, kết quả âm tính. Có 5 bệnh nhân được làm PCR lao, kết quả kều âm tính.

Siêu âm ổ bụng tổng quát phát hiện được dịch tự do ổ bụng trên tất cả 38 bệnh nhân, tìm thấy hạch ổ bụng ở 6 bệnh nhân. Trong khi đó chụp cắt lớp vi tính ổ bụng khảo sát được dịch ổ bụng trên $100 \%$ các bệnh nhân, 14(36,8\%) bệnh nhân thấy được hạch ổ bụng và có $10(26,3 \%)$ bệnh nhân có biểu hiện dày phúc mạc.

3.3. Kết quả phẫu thuật nội soi ổ bụng chẩn đoán. Thời gian mổ trung bình là 49,5 \pm 9,1 phút, nhanh nhất là 35 phút, chậm nhất là 65 phút. Tất cả các ca mổ đều thành công, không có tai biến trong mổ. Có $34(89,5 \%)$ trường hợp sử dụng 3 trocars, có 4 trường hợp chỉ sử dụng 2 trocars.

Lượng dịch ổ bụng kiểm tra được trong ổ bụng trung bình là $367,1 \pm 222,5 \mathrm{ml}$, nhiều nhất là $1100 \mathrm{ml}$, ít nhất là $50 \mathrm{ml}$. Dịch ố bụng chủ yếu là dịch tiết vàng chanh với 36 (94,7\%) bệnh nhân, 2 trường hợp còn lại là dịch hồng. Trong đó có 28 bệnh nhân chúng tôi lấy dịch ổ bụng qua nội soi đưa ra làm xét nghiệm nuôi cấy dịch tìm vi khuẩn, kết quả chỉ có $3(10,7 \%)$ bệnh nhân tìm được trực khuẩn lao, 25 bệnh nhân âm tính.

Kết quả giải phẫu bệnh của bệnh phẩm lấy được qua nội soi ổ bụng là 34(89,5\%) bệnh nhân lao phúc mạc, $1(2,6 \%)$ ung thư di căn, $3(7,9 \%)$ viêm mạn tính.

Kết quả chẩn đoán bệnh lý thành công $100 \%$ bênh nhân với 34 bệnh nhân bị lao phúc mạc, 03 bệnh nhân bị viêm ruột mạn tính và 01 bệnh nhân bị ung thư di căn phúc mạc. Thời gian nằm viện trung bình là 4,6 ngày.

\section{BÀN LUẬN}

Trong các bệnh lý bụng chướng, đau bụng mạn tính, việc chẩn đoán xác định và đưa ra phác đồ điều trị là rất khó khăn, đặc biệt là khi các công cụ chẩn đoán cận lâm sàng thông thường không thể xác định chính xác nguyên nhân của bệnh. Nội soi ổ bụng chẩn đoán đã trở thành một phương pháp hiệu quả để chẩn đoán chính xác bệnh lý trong ổ bụng, tránh mở bụng 
thăm dò không cần thiết và góp phần đưa ra hướng điều trị đúng cho bệnh nhân [6].

Trong số 38 bệnh nhân, số bệnh nhân nam nhiều hơn số bệnh nhân nữ lần lượt tương ứng là $52,6 \%$ và $47,4 \%$. Tỷ lệ nam/nữ là $1,1 / 1$. Trong nghiên cứu của Chetan R Kulkarni tại Ấn Độ tỳ lệ này là $49 \%$ nam và $51 \%$ nữ [3].

Trong nghiên cứu của chúng tôi, bênh nhân tuổi cao nhất là 90 tuổi, thấp nhất là 17 tuổi, độ tuổi trung bình của nhóm nghiên cứu là $52,3 \pm$ 17,8. Trong nghiên cứu của Chetan và cộng sự, độ tuổi của bệnh nhân là từ 16 đến 60 tuổi, độ tuổi trung bình là 49 tuổi [3].

Trong nghiên cứu này, bệnh nhân nhập viện với triệu chứng bụng chướng tăng dần với tỷ lệ $97,4 \%$, thường xuyên đau tức bụng âm ì trên 63,2\% số bệnh nhân, kèm theo sốt ớn lạnh và rối loạn tiêu hóa với tỷ lệ $67,9 \%$ và $63,2 \%$ các bệnh nhân. Trong nghiên cứu của Kallakuri, 93\% bệnh nhân có triệu chứng đau bụng kéo dài và chướng bụng, chỉ có $46 \%$ có dấu hiệu sốt nhẹ và 275 có rối loạn tiêu hóa kéo dài [6].

Phản ứng IDR (Intra dermic reaction) với Tuberculin được dùng để phát hiện người đã nhiễm lao cũng như tiên lượng điều trị lao [2]. Trong nghiên cứu của chúng tôi có 31 bệnh nhân được làm phản ứng lao tố IDR cho kết quả 10 bệnh nhân dương tính. Theo hiệp hội lồng ngực Mỹ, tỷ lệ IDR dương tính trên bệnh nhân không có triệu chứng lâm sàng rõ ràng cũng như đã điêu trị lao là $11,2 \%$ [2]. Với các bệnh nhân IDR dương tính chỉ cho định hướng nghĩ tới bênh cảnh do lao mà không khẳng định được chắc chắn nguyên nhân do lao.

Tất cả 38 bệnh nhân xét nghiệm dịch ổ bụng có kết quả Rivalta $(+)$ và mức Protein dịch đều trên $30 \mathrm{~g} / \mathrm{L}$. Điều này cho thấy dịch ổ bung của các bệnh nhân trong nghiên cứu đều là dịch tiết, thường gặp trong bệnh lý viêm lao, nhiễm khuẩn, ung thư. Các nghiên cứu của các tác giả khác đều cho kết qủa tỷ lệ dịch tiết chiếm gần như toàn bộ các bệnh nhân. Nghiên cứu của Chetan $\mathrm{R}$ có tỷ lệ dịch tiết là $87,5 \%$ [3] và $94 \%$ với nghiên cứu của Han CM và cộng sự [5].

Các triệu chứng lâm sàng, xét nghiệm máu khác đều không có biểu hiện bệnh lý đặc hiệu. Nhìn sơ bộ nghĩ tới bệnh lý nhiễm lao. Nhưng trong số 31 bệnh nhân có IDR dương tính, chúng tôi chỉ tiến hành làm xét nghiệm PCR lao trên 5 bệnh nhân, cho kết quả là âm tính, không thể khẳng định bệnh lý ổ bụng do lao.

Siêu âm ổ bung có thể phát hiện dịch tự do ổ bung tối thiểu là $100 \mathrm{ml}$ và cắt lớp ổ bung có thể phát hiện với lượng dịch ít hơn. Trong nghiên cứu của chúng tôi, siêu âm ổ bụng và chụp cắt lớp vi tính chỉ khảo sát được dịch ổ bụng với $100 \%$ bệnh nhân, nhưng chỉ có 36,8\% tìm được hạch trong ổ bụng và $26,3 \%$ tìm được dấu hiệu thâm nhiễm phúc mạc. Kết quả này cũng tương ứng với nghiên cứu của Han CM [5] và của nhóm Salky BA [8]. Dù các nghiên cứu cho thấy các phương pháp chẩn đoán hình ảnh ngày càng phát triển làm giảm việc sử dụng phẫu thuật nội soi để chẩn đoán các bệnh lý trong ổ bụng. Tuy nhiên, phẫu thuật nội soi ổ bụng chẩn đoán với việc quan sát trực tiếp cũng như sinh thiết qua nội soi giúp cho việc chẩn đoán nguyên nhân bệnh lý ổ bụng hiệu quả, chính xác hơn và không thể thay thế hoàn toàn.

Thời gian phẫu thuật trung bình 49,5 $\pm 9,1$ phút, nhanh nhất là 35 phút và lâu nhất là 65 phút. Thời gian mổ trong nghiên cứu không có sự khác biệt lớn với các nghiên cứu của các tác giả khác. Nghiên cứu của Kallakuri Sailaja [6] thời gian mổ trung bình là 52 phút. Phẫu thuật nội soi ổ bụng chẩn đoán là phấu thuật xâm lấn tối thiểu, thời gian phẫu thuật tương đối nhanh, giảm thiểu các nguy cơ biến chứng do phẫu thuật và gây mê.

Trong nghiên cứu của chúng tôi số lượng dịch tự do ổ bụng trung bình là: $367,1 \pm 222,5 \mathrm{ml}$. Tính chất dịch tự do ổ bụng của các bệnh nhân trong nghiên cứu chủ yếu là dịch vàng chanh với tỷ lệ $94,7 \%$ và dịch hồng với 5,3\%. Trong nghiên cứu của Salky BA và cộng sự, tính chất dịch ổ bụng quan sát được trong mổ chủ yếu là dịch vàng chanh với $56 \%$ bênh nhân và $43 \%$ có dịch hồng, $1 \%$ có lẫn máu cục [8]. Như vậy có thể thây ưu điểm vượt trội của nội soi ổ bụng thăm dò là ngoài việc chẩn đoán xác định có dịch ổ bung với số lượng dịch chính xác còn cho biết số lượng và tính chất của dịch giúp hướng tới nguồn gốc của dịch, đây là ưu điểm vượt trội mà các thăm dò cận lâm sàng khác không có.

Trong nghiên cứu của chúng tôi, tất cả các ca mổ đều thành công, không có bệnh nhân nào bị tai biến trong mổ. Theo nghiên cứu của Han CM tỉ lệ mổ thất bại là $15 \%$ do không đặt được trocars hoặc sinh thiết thất bại [5].

Thời gian nằm viện trung bình của cả nhóm nghiên cứu là 4,6 \pm 1,2 ngày, kết quả này có sự khác biệt với các nghiên cứu của các tác giả khác. Trong nghiên cứu của Kallakuri Sailaja, thời gian nằm viện điều trị của bệnh nhân trung bình là 8 ngày [4]. Tại Sau khi chẩn đoán xác định được bệnh lý ổ bụng, bệnh nhân được hội chẩn và chuyển tới chuyên khoa điều tri phù hợp.

Tổng kết nghiên cứu của chúng tôi chẩn đoán 
xác định được bệnh lý ổ bụng của cả 38 bệnh nhân với $34(89,5 \%)$ bệnh nhân được chẩn đoán với kết quả giải phẩu bệnh là lao phúc mạc, có $3(7,9 \%)$ bệnh nhân kết quả là viêm mạn tính và $1(2,6 \%)$ bệnh nhân là ung thư di căn phúc mạc. Kết quả của chúng tôi khác với các nghiên cứu khác trên thế giới. Trong nghiên cứu của Chetan R Kulkarni chẩn đoán thành công $90 \%$ bệnh nhân, với kết quả $57 \%$ lao phúc mạc, $25 \%$ ung thư di căn phúc mạc, $5 \%$ xơ gan và $10 \%$ viêm phúc mạc không rõ nguyên nhân [3]. Trong khi đó, nghiên cứu của Han $\mathrm{CM}$ và cộng sự chẩn đoán thành công $84,6 \%$ các bệnh nhân, trong đó $56,2 \%$ là ung thư di căn phúc mạc, $19 \%$ xơ gan và $17,6 \%$ là do lao phúc mạc [5]. Ở các nước phát triển, điều kiện kinh tế xã hội ở mức cao, tỷ lệ mắc lao thấp hơn ở các nước đang phát triển, nguyên nhân gây ra các bệnh lý mạn tính ổ bụng hàng đầu là ung thư di cằn ổ bụng, sau đó là bệnh lý gan, lao phúc mạc và viêm man tính.

\section{KẾT LUÂ̂N}

Nghiên cứu của chúng tôi áp dụng phẫu thuật nội soi chẩn đoán bệnh lý ổ bụng với các chỉ định chính: tràn dịch ổ bụng, hạch trong ổ bụng, đau bụng man tính không tìm được nguyên nhân chính xác bằng các lâm sàng và cận lâm sàng. Tất cả các bệnh nhân được chẩn đoán thành công nguyên nhân gây ra bệnh lý trong ổ bụng bằng phẩu thuật nội soi chẩn đoán. Đa số nguyên nhân gây bệnh lý ổ bụng được chẩn đoán do lao phúc mạc, một số trường hợp do viêm ruột mạn tính và ung thư di căn phúc mạc.

Nội soi ổ bụng chẩn đoán là phương pháp an toàn, nhanh chóng, hiệu quả và chính xác để chẩn đoán nguyên nhân gây ra các bệnh lý trong ổ bụng, phục vụ điều trị cho bệnh nhẩn.

\section{TÀI LIÊU THAM KHẢO}

1. Amandeep S Nar, Ashvind Bawa, Atul Mishra, and Amit Mittal. Role of Diagnostic Laparoscopy in Chronic Abdominal Conditions with Uncertain Diagnosis; 2014; 20(2): 75-78.

2. American Thoracic Society. Diagnostic standards and classification of tuberculosis. Tuberculin skin test. Am Rev Respir Dis; 1990; 142:732-5.

3. Chetan R Kulkarni, et al. Laparoscopy as a Diagnostic Tool in Ascites of Unknown Origin; 2018; 21(2): 124-131.

4. Davis CJ, Filipi $\mathbf{C J}$ et al. History of endoscopic surgery. In: Arregui ME; Principles of Laparoscopic Surgery: Basic and Advanced Techniques. New York: Springer-Verlag; 1995; 112: 79-83.

5. Han CM et al. Diagnostic laparoscopy in ascites of unknown origin: Chang Gung Memorial Hospital 20-year experience. Chang Gung Med J; 2008; 31(4):378-383.

6. Kallakuri Sailaja et al. Role of Diagnostic Laparoscopy in Chronic Abdominal Pain; 2018; 16(1): 65-72.

7. Porcel A. Value of laparoscopy in ascites of undetermined origin. Rev Esp Enferm Dig; 1996; 88(7): 485-9.

8. Salky BA, Edye MB. The role of laparoscopy in the diagnosis and treatment of abdominal pain syndromes. Surg Endosc; 1998; 12(7):911-914.

\section{NGHIÊN CỨU Đİ̀̃U TRI CÁC TRƯỜNG HỢP CHỬA SẸO MỔ LẤY THAI BẰNG PHẪU THUÂ̂T TẠI BỆNH VIỆN PHỤ SẢN TRUNG ƯO'NG}

\section{TÓM TẮT}

Mục tiêu: Mô tả điều trị phẫu thuật các trường hợp chửa sẹo mổ lấy thai tại Bệnh viện Phụ sản Trung ương. Phướng pháp: Tiến cứu mô tả. Kểt quả: Các trường hợp mố mở lấy khối chửa bảo tồn tử cung chiếm tỷ lệ là $83,1 \%$, mổ cắt tử cung bán phần là 13,5\%, mố nội soi lấy khối chửa chiếm 3,4\%. Nguyên nhân chuyển phương pháp nhiều nhất là chảy máu có 23 trường hợp. Có 14 trường hợp có tai biến chảy

\footnotetext{
${ }^{1}$ Bệnh viện Phụ sản Trung ương

²Bênh viện đa khoa Gia Lâm

Chịu trách nhiệm chính: Nguyễn Quảng Bắc

Email: drbacbvpstw@gmail.com

Ngày nhận bài: 12.4.2021

Ngày phản biện khoa học: 25.5 .2021

Ngày duyệt bài: 14.6.2021
}

\section{Nguyễn Quảng Bắc ${ }^{1}$, Nguyễn Thị Kim Ngân ${ }^{2}$}

máu chiếm 23,7\%. Kết luân: Phẫu thuật các trường hợp chửa sẹo mổ lấy thai chủ yếu là mổ lấy khối chửa bảo tồn tử cung.

Tư khoá: Chửa sẹo mổ lây thai.

\section{SUMMARY}

STUDY ON OUTCOME OF SURGICAL TREATMENT OF CESEAREAN-SECTION PREGNANCY AT NATIONAL HOSPITAL OF OBSTETRICS AND GYNECOLOGY

Objectives: To describe surgical treatment of cesearean-scar pregnancy at National hospital of obstetrics and gynecology. Methodology: this is a prospective study among 59 patients who were diagnosed with C-section pregnancy. Results: Open surgery for uterus preservation was $83,1 \%$, partial hysterectomy was $13,5 \%$, laparoscopy removal of pregnancy was $3,4 \%$. Bleeding is the most common 